DOI: 10.15587/2706-5448.2021.237172

Article type «Reports on Research Projects»

\section{Ivan Stepanets, Leila Shafiieva}

\title{
DEVELOPMENT OF CONCEPTUAL PROVISIONS FOR INVESTMENT SUPPORT OF BALANCED SOCIO-ECONOMIC DEVELOPMENT OF THE REGION
}

The object of research is the organizational-economic and organizational-managerial relations that arise in the process of managing investment processes in the region. One of the most problematic places is insufficiently disclosed issues on the theoretical and methodological platform for investment support of balanced socio-economic development of the region.

The paper is based on theoretical and methodological provisions concerning the development of a promising regional strategy for investment development, taking into account the world scientific experience and effective management practice, and the study of the problems of investment development of the regional economy. The study used the method of monographic analysis and comparison to develop a conceptual and categorical apparatus of «regional strategy». Methods of scientific analysis, synthesis and analogies were used to study the development of a promising regional strategy for investment development. And the historical-logical method was used to determine the strategy as a method of setting long-term goals of the organization, its program of actions and priority areas for the allocation of resources.

The research result was a content analysis of the content of the definition of «strategy» and «investment strategy». The investment strategy is interpreted as a general direction (program, plan) of investment activities in the region, the passage of which in the long run should lead to the achievement of investment goals and the expected economic effect. An important aspect in the organization of the investment process in the region is determined by the organizational and economic mechanism that regulates the behavior of agents engaged in investment activities. Conceptual provisions of investment support of balanced social and economic development of the region are formed. The author's vision of the investment strategy of the region allows to supplement and clarify its substantive aspects from the standpoint of considering this category as a long-term, high-quality process of providing the region with investment resources in order to achieve sustainable balanced development.

The research results may be interesting in the further development and addition of theoretical provisions, methods and procedures that contribute to the study of areas and means of investment for balanced socio-economic development of the region.

Keywords: regional strategy, investment strategy, management of investment process, organizational and economic mechanism, balanced development of the region.

\section{How to cite}

Stepanets, I., Shafiieva, L. (2021). Development of conceptual provisions for investment support of balanced socio-economic development of the region. Technology Audit and Production Reserves, 4 (4 (60)), 52-56. doi: http://doi.org/10.15587/2706-5448.2021.237172

\section{Introduction}

The socio-economic development of the region is characterized as a complex and multi-level process to achieve a set of various goals, both social and economic (growth in production; incomes of the population, changes in social, institutional structures, etc.).

At the same time, it should be aimed at achieving a balance between the various types and areas of activity in the region.
The need to solve modern problems of the balanced development of territories actualizes the directions of scientific research. These directions are devoted to the search for organizational and economic mechanisms to reduce the socio-economic asymmetry in the region, to increase the level of use of various types of resources, development of interregional integration, ensuring sustainability and balance.

Thus, today there is an extremely important condition for the strategic development of the region in the form of new approaches and methods to increase the efficiency 
of investment processes in the region, which is due to a number of interrelated circumstances:

- firstly, investments are a means of forming a stable balanced structure of the regional economy, the growth of the gross regional product and other indicators that characterize the dynamics of socio-economic development. The volume of investments and the efficiency of their use affect the results of economic activity at all levels of the economic system. Investment activity and economic growth are interconnected and interdependent, in this connection, the management of investment processes is of key importance, both for individual economic entities, regions, and the country as a whole;

- secondly, in order to achieve a synergistic effect from the implementation of the investment strategy for the development of the territory, it is necessary to identify the mission of the region and the tasks of its socio-economic development, based on the principles of taking into account the interests of stakeholders. This will contribute to obtaining maximum efficiency due to the joint focus of the parties on the final result; - thirdly, new instruments of regional management are rapidly entering the economic turnover (including clusters with the participation of social organizations; strategies for the development of municipalities; publicprivate partnership projects implemented in education, healthcare, the ecosphere, etc.). This requires new appropriate forms of their investment support, in particular, project financing;

- fourthly, investment activity in the regions is closely related to the processes of international globalization and internationalization. Despite the destabilization of international relations, domestic and foreign investors still have opportunities to move production in the global economic space, as well as financial instruments. Appropriate actions contribute to the flow of capital between territories, which must be taken into account when forming and implementing an investment strategy for the development of the region;

- fifthly, in the implementation of effective regulation of regional investment processes, the role of the state is extremely important, including as a participant in interbudgetary relations. Regions with budget deficits make it much more difficult to implement investment initiatives. Therefore, the problems of improving the quality of revenue sources and expenditure obligations of the regional budget are actualized in order to create a basis for the effective use of financial resources, increase investment attractiveness, and socio-economic development of the region.

In scientific works [1-3], it is noted that investment is an integral part of the modern economy. The investment strategy is defined as the long-term qualitative and quantitative development of an organization, region, country. This development occurs due to the creation of a sphere of activity, means and forms of functioning, as well as relationships in the system of internal and external environments, an object of development until the achievement of the formed goals. Moreover, the strategy is defined and processed as a process of transformation and a process of implementing the plan $[4,5]$.

Therefore, the issue of investment support for balanced socio-economic development of regions is relevant. Thus, the object of research is the organizational-economic and organizational-managerial relations arising in the process of managing investment processes in the region. And the aim of research is to clarify and develop theoretical provisions, methods and procedures that contribute to the definition of directions and means of investment support for the balanced socio-economic development of the region.

\section{Methods of research}

The research used the following methods are used: - method of monographic analysis and comparison for the development of the conceptual and categorical apparatus of the «strategy of the region», specifying its substantive aspects;

- methods of scientific analysis, synthesis and analogies - when studying the development of a promising regional strategy for investment development, taking into account world scientific experience and effective management practice;

- historical and logical method - in determining the strategy as a method for establishing long-term goals of the organization, its program of actions and priority areas for the allocation of resources.

Considered and systematized scientific theories that made it possible to develop a content analysis of the content of the strategy as a category.

\section{Research results and discussion}

Investment is a basic factor in the formation of a balanced structure of the regional economy, the growth of the gross regional product and other indicators characterizing the dynamics of socio-economic development. The volume of investments and the efficiency of their use are reflected in the results of financial and economic activities at all levels of the economic system. Investment activity and economic growth are interrelated and interdependent, and therefore, the management of investment processes is of key importance, both for individual economic entities, regions, and the country as a whole. The most complete and effective implementation of the region's potential is ensured only with a systemic strategic approach. A strategic approach to the implementation of investment activities requires the formation of such a model of socio-economic development of the region, which is aimed at achieving long-term parameters of investment planning. Also, this model should make it possible to get rid of the role of an «adapter» of investment projects launched from the mountain, to limit the practice of regional authorities in the mode of operational situational response. This approach makes it possible to move from the implementation of individual investment projects to the creation of an integral system of regional investment planning. This requires the formation and implementation of an investment strategy as an operating long-term system, and not a formal reporting document.

The relevance of measures to develop an investment strategy for the balanced development of the region is due to a number of circumstances:

- firstly, the work of regional public authorities on strategic plans and programs systematizes information about the region, contributes to the development of priorities for socio-economic development, identification of progressive industries; 
- secondly, the investment development strategy is an important factor in the spread of the investment attractiveness of the region and the formation of a modern investment infrastructure. The implementation of the investment infrastructure contributes to the development of effective instruments for creating favorable investment conditions in the region, aimed at ensuring a stable inflow of investments;

- thirdly, the strategy ensures not only the quantitative growth of investments, but also the qualitative parameters of the sustainable balanced development of the region, which are reflected in social and budgetary efficiency.

For sustainable long-term investment development of the region, it is necessary to develop a comprehensive document on investment development, which will define strategic investment priorities: territories of advanced development, progressive industries, and advanced technologies. Thus, the prospect of creating and implementing an investment strategy for the development of the region is to move from a situational response to socio-economic challenges to systematic work to create a sustainable balanced economy of the region.

Content analysis of the content of the strategy as a category is presented in Table 1.

Table 1

Content analysis of the content of the "strategy" definition

\begin{tabular}{|l|c|}
\hline \multicolumn{1}{|c|}{ Approaches to the definition of «strategy» } & Source \\
\hline $\begin{array}{l}\text { Strategy as a method for setting long-term goals of an organization, } \\
\text { a program of its actions and priority directions for the allocation } \\
\text { of resources. Strategy is the overarching orientation of plans or } \\
\text { actions that sets the critical direction and controls the allocation } \\
\text { of resources. It is the focus of action, which is the «best guess» } \\
\text { of what needs to be done to ensure long-term prosperity }\end{array}$ & {$[1,6]$} \\
\hline $\begin{array}{l}\text { Strategy as a method for determining the competitive goals of } \\
\text { an organization }\end{array}$ & {$[7]$} \\
\hline $\begin{array}{l}\text { Strategy as a way of responding to external opportunities and } \\
\text { threats, internal strengths and weaknesses }\end{array}$ & {$[3,8]$} \\
\hline $\begin{array}{l}\text { Strategy as a way of setting goals for corporate, business and } \\
\text { functional levels }\end{array}$ & {$[4,9]$} \\
\hline $\begin{array}{l}\text { Strategy as a consistent, coherent and integrated structure of } \\
\text { management decisions }\end{array}$ & {$[5,10]$} \\
\hline $\begin{array}{l}\text { Strategy as a pattern, or plan, integrating the main goals of } \\
\text { the organization, its policies and actions into a coherent whole }\end{array}$ & {$[7]$} \\
\hline $\begin{array}{l}\text { The essence of the strategy is to create competitive advantages } \\
\text { tomorrow faster than competitors can imitate those that you } \\
\text { own today }\end{array}$ & {$[7,11]$} \\
\hline $\begin{array}{l}\text { Strategy as a set of actions and approaches to achieve the set } \\
\text { performance indicators }\end{array}$ & {$[6,12]$} \\
\hline
\end{tabular}

The strategy should contain clear goals, the achievement of which is decisive for the overall outcome of the case, support the initiative and focus the main efforts at the right time in the right place. And also to provide for such flexibility of behavior in order to use a minimum of resources to achieve maximum results, to designate coordinated leadership, to assume the correct schedule of actions, to provide guaranteed resources.

The strategy acts not only as a tool for substantiation, development and implementation of long-term goals and objectives of production, scientific and technical, economic, organizational and social nature. It is also a powerful factor that regulates the activities of the organization until the intended goals and objectives are achieved. At the same time, it acts as a means of communication between the enterprise and the external market environment.

Thus, strategy is the art of planning leadership based on long-term forecasts. At the same time, priority tasks and directions for the development of various forms of activity and the development of a mechanism for their implementation are highlighted [7].

In turn, the investment strategy is an effective tool for the long-term management of investment activities in the region (Table 2).

Table 2

Content analysis of the content of the definition of «investment strategy»

\begin{tabular}{|l|c|}
\hline Approaches to defining the content of an investment strategy & Source \\
\hline $\begin{array}{l}\text { The system helps to attract foreign and domestic investors by } \\
\text { building a favorable investment infrastructure and in the pre- } \\
\text { sence of investment attractiveness }\end{array}$ & [13] \\
\hline $\begin{array}{l}\text { A document defining the economic policy of the enterprise and } \\
\text { management, aimed at achieving long-term development goals, } \\
\text { the implementation of which will ensure the effective functioning } \\
\text { of the economy and rapid adaptation to the external environment }\end{array}$ & [14] \\
\hline \begin{tabular}{l} 
System of goals and priorities of investment activity \\
\hline $\begin{array}{l}\text { A set of interrelated strategic decisions, including the choice, } \\
\text { priorities and size of the use of possible sources of attracting } \\
\text { and spending financial resources }\end{array}$
\end{tabular} & [16] \\
\hline $\begin{array}{l}\text { A complex of interrelated strategic decisions, including the choice, } \\
\text { priorities and size of the use of possible sources of attracting } \\
\text { and spending financial resources }\end{array}$ & [17] \\
\hline $\begin{array}{l}\text { A set of measures to stimulate the development of knowledge- } \\
\text { intensive industries, create prerequisites and opportunities for } \\
\text { investment activity of domestic and foreign investors Purposeful } \\
\text { activities to identify the most important areas of investment } \\
\text { financing, select priorities for capital-intensive development and } \\
\text { develop the necessary measures }\end{array}$ & {$[18]$} \\
\hline
\end{tabular}

The strategy sets the standards to be followed by economists who are responsible for managing investments. It defines the basis for the actions of strategic decision makers.

An investment strategy can be presented as a general direction (program, plan) of investment activities in the region, following which in the long term should lead to the achievement of investment goals and the expected economic effect.

Management of investment support for the balanced development of the region creates a unified information field and basis for the implementation of the investment strategy in the region (Fig. 1).

An important aspect of the organization of the investment process in the region is the definition of the organizational and economic mechanism that regulates the behavior of agents carrying out investment activities.

The organizational mechanism for the implementation of the investment strategy includes the rule-making and general regulatory policy, determines the legal conditions for the implementation of investment activities in the region. This mechanism is a system of mandatory requirements and orders of public authorities of the region in relation to agents of investment activities.

The economic mechanism for implementing an investment strategy is aimed at regulating the economic behavior of investment agents. This mechanism provides for the use of tax, monetary, budget elements of influence. 


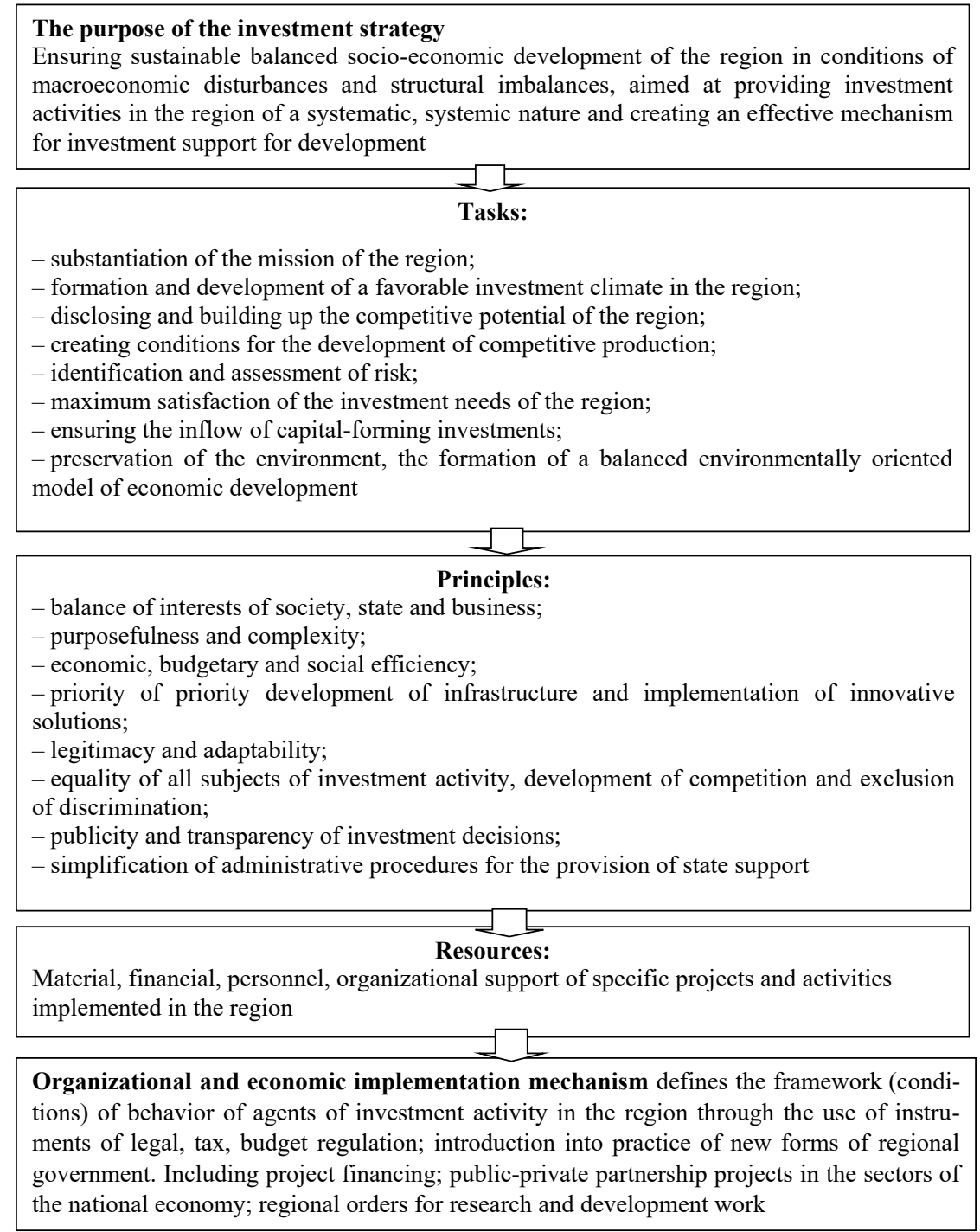

Fig. 1. Conceptual provisions of investment support for balanced socio-economic development of the region (author's development)

The investment strategy is designed to ensure the confident achievement of the goals of innovative and investment development of the regions and the formation of a sustainable investment process in relation to possible risks.

Regional investment strategy is a multifunctional and multi-level system of relationships between investment agents regarding the attraction and use of investments. This system is determined by the socio-economic dynamics of the development of the region, its resource base, as well as the balance of interests of the state and private structures present in the region. Under such conditions, the authors supplemented and clarified the substantive aspects of the «investment strategy» from the perspective of considering this category as a long-term, well-defined process of providing the region with investment resources in order to achieve sustainable balanced development.

Let's agree with the point of view of the researchers, they note that at present it is almost impossible to accurately predict the conditions of the external environment in the long term. Since the risks have increased dramatically, an investment strategy is needed as a technology for making and implementing investment decisions in difficult conditions [13-15].
Since the conditions of the external environment are not stable, poorly predictable, the planning of investment support for the socio-economic development of the region should be based on the strategy of investment development.

\section{Conclusions}

In the course of the study, the definition of the «investment strategy of the region» has been improved. Its substantive aspects have been supplemented and refined from the perspective of considering this category as a longterm, qualitatively defined process of providing the region with investment resources in order to achieve sustainable balanced development. As a result of the research, a content analysis of the content of the definitions «strategy» and «investment strategy» appeared. Conceptual provisions for investment support for balanced socio-economic development of the region have been formed. It has been revealed that the most difficult link in the chain of creating and ensuring the balanced development of the region is the managerial interaction of the executive bodies of state power with other groups interested in regional development. When forming an investment strategy, it is important to clearly 
define the parameters of the investment process, which the subject of management seeks to achieve in the future. This condition will ensure the formation of an effective organizational and economic mechanism for their achievement, taking into account the influence of the changing conditions of the macroenvironment. The content of the investment strategy reflects not just investment priorities or planning before the implementation of investment projects, but a holistic vision of the investment process in the future, in conjunction with the balanced socio-economic development of the territory as a whole.

The research results may be of interest in the further development and addition of theoretical provisions, methods and procedures that contribute to the study of directions and means of investment support for a balanced socioeconomic development of the region.

\section{References}

1. Luong, B. V., Tai, D. A., Xuan, T. T. T. (2019). Factors Affecting the Satisfaction of Non-State Enterprises When Investing in Thai Nguyen Province. Journal of Business Management and Economic Research, 3 (11), 42-52. doi: http://doi.org/10.29226/ tr1001.2020.170

2. Bugg-Levine, A., Goldstein, J. (2009). Impact investing: harnessing capital markets to solve problems at scale. Community Development Investment Review, 2, 30-41.

3. Arnott, R., Harvey, C. R., Kalesnik, V., Linnainmaa, J. (2019). Alice's Adventures in Factorland: Three Blunders That Plague Factor Investing. The Journal of Portfolio Management, 45 (4), 18-36. doi: http://doi.org/10.3905/jpm.2019.45.4.018

4. Da Rin, M., Penas, F. (2017). Venture capital and innovation strategies. Industrial and Corporate Change, 26 (5), 781-800. doi: http://doi.org/10.1093/icc/dtw052

5. Alawi, S. M., Ali, S. H. (2020). Investing In The Iraqi Economy: Opportunities And Challenges. Palarch's Journal Of Archaeology Of Egypt/Egyptology, 17 (4), 2419-2431.

6. Chandler Jr., A. D.. (1962). Strategy and Structure: Chapters in the History of the Industrial Enterprise. Cambridge: MIT Press, 297.

7. Brovkova, O. (2017). Stratehichnyi menedzhment. Kyiv: Tsentr navchalnoi literatury, 224.
8. Porter, M. E. (1998). Competitive Strategy: Techniques for Analyzing Industries and Competitors. Free Press, 397.

9. Ansoff, H. (2007). Strategic Management. Palgrave Macmillan, 233. doi: http://doi.org/10.1057/9780230590601

10. Mintzberg, H., Lampel, J., Ahlstrand, B. (2005). Strategy Safari: A Guided Tour Through The Wilds of Strategic Management. Free Press, 416.

11. Hamel, G. (1993). Strategy as stretch and leverage. Harvard business review, 71 (2), 75 .

12. Thompson, A. A., Strickland, A. J., Thompson, J. (1999). Strategic Management. McGraw-Hill Companies, 1088.

13. Butko, M. P., Ditkovska, M. Yu., Zadorozhna, S. M. (2016) Stratehichnyi menedzhment. Kyiv: Tsentr uchbovoi literatury, 376

14. Grinko, P. L. (2016). The study of the investment policy formation of the enterprises as an important factor of their strategic development. Technology Audit and Production Reserves, 1 (3 (27)), 63-68. doi: http://doi.org/10.15587/23128372.2016.60790

15. Papka, O. S. (2015). Zasady formuvannia instytutsiinoho seredovyshcha investytsiinoi diialnosti v Ukraini. Naukovyi visnyk NLTU Ukrainy. Ser «Ekonomichna», 25.7, 251-254.

16. Kaminskyi, A. B., Lomovatska, Ya. V. (2011). Kontseptualni osnovy rozrobky investytsiinykh stratehii instytutiv kolektyvnoho investuvannia. Investytsii: praktyka ta dosvid, 10, 3-8. Available at: http://nbuv.gov.ua/UJRN/ipd_2011_10_3 Last accessed: 08.06.2021

17. Sydorov, I. (2019). Formation of innovation-investment strategy for enterprise development. Investytsiyi: Praktyka Ta Dosvid, 3, 72-76. doi: http://doi.org/10.32702/2306-6814.2019.3.72

18. Panukhnyk, O. V. (2011). Metodychne zabezpechennia stratehichnoho planuvannia v rehionakh Ukrainy. Aktualni Problemy Ekonomiky, 1 (91), 152-157.

Ivan Stepanets, PJSC «Higher Educational Institution «Interregional Academy of Personnel Management», Kyiv, Ukraine, ORCID: https:// orcid.org/0000-0002-8614-2186

$\triangle$ Leila Shafiieva, PJSC «Higher Educational Institution «Interregional Academy of Personnel Management», Kyiv, Ukraine, ORCID: https:// orcid.org/0000-0002-6284-3607, e-mail: leila.shafiieva@gmail.com

$\bowtie$ Corresponding author 